
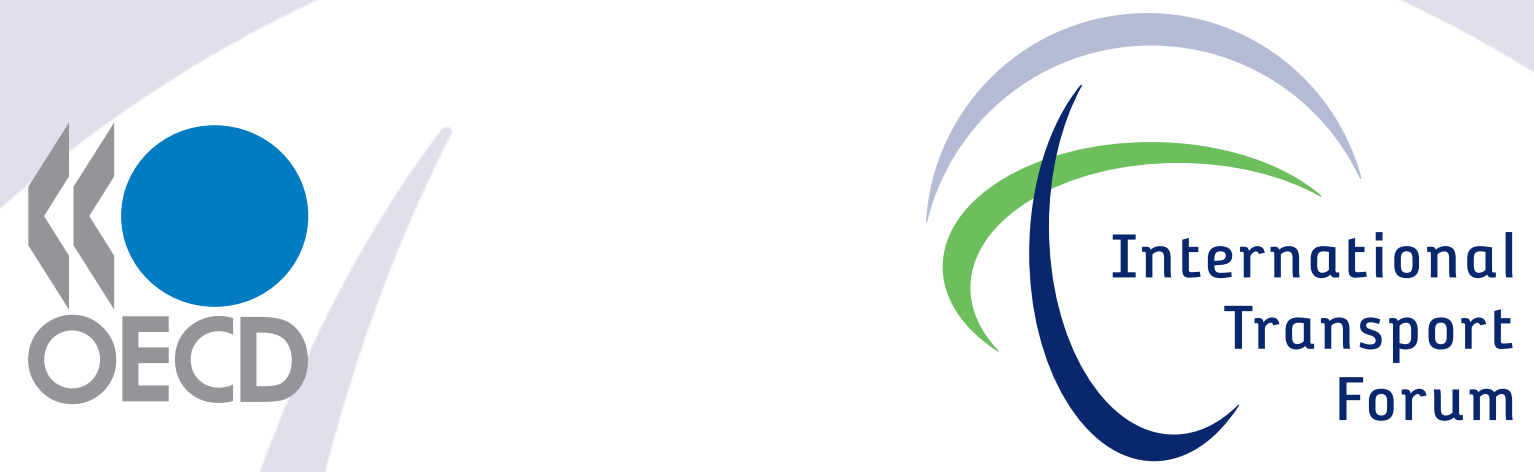

J OINT TRANSPORT RESEARCH CENTRE

$$
\begin{array}{r}
\text { Discussion Paper No. 2008-17 } \\
\text { September } 2008
\end{array}
$$

\title{
Impacts of Airports on Airline
} Competition: Focus on Airport Performance and AirportAirline Vertical Relations

\section{Tae H. OUM}

The Air Transport Research Society (ATRS) and University of British Columbia, Canada

Xiaowen FU

Hong Kong Polytechnic University

Hong Kong, China 

Discussion Paper No. 2008-17

Prepared for the Round Table of 2-3 October 2008 on

Airline Competition, Systems of Airports and Intermodal Connections

Draft of 10 September 2008

Not to be quoted without the authors' permission. Comments Welcome.

Impacts of Airports on Airline Competition:

Focus on Airport Performance and Airport-Airline Vertical Relations

Tae H. Oum,

The Air Transport Research Society (ATRS) and

University of British Columbia, Canada

Tae.oum@ubc.ca

And

Xiaowen Fu, Hong Kong Polytechnic University

Hong Kong, China

Igtxfu@polyu.edu.hk

September 2008

The views expressed in this paper are those of the authors and do not necessarily represent positions of the University of British Columbia and

Hong Kong Polytechnic University, the OECD or the International Transport Forum. 



\section{TABLE OF CONTENTS}

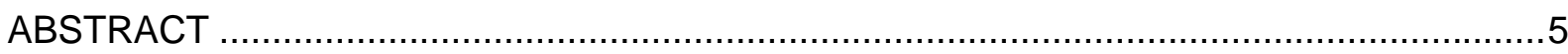

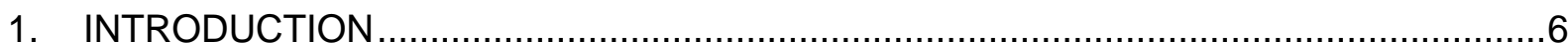

2. AIRPORT REVENUE STRUCTURE, REGULATION AND PRICING ...........................

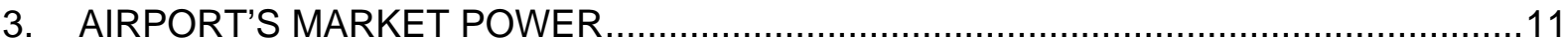

3.1. Airport capacity and demand for that capacity ..................................................

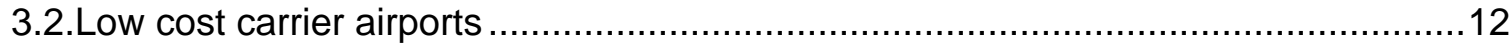

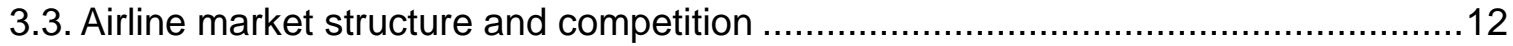

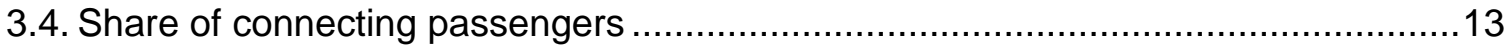

3.5. Intermodal competition, especially between airlines and high speed rail ................13

3.6. Competition among airports in the same metropolitan region ...............................14

4. AIRPORT DOMINANCE AND AIRLINE HUB PREMIUM, AND IMPLICATIONS FOR AIRLINE-AIRPORT COOPERATION ............................................................... 15

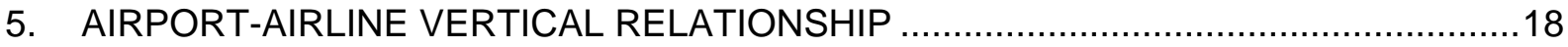

5.1. The costs and benefits of airport-airline integration.........................................

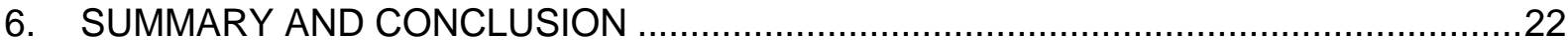

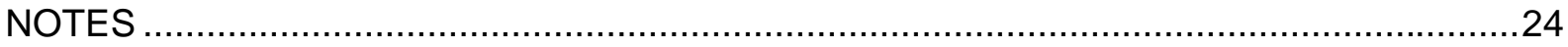

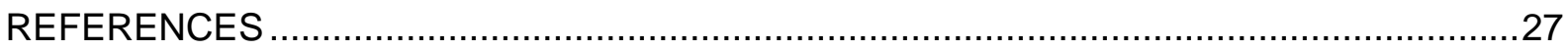

Appendix A. Alternative forms of economic regulation of airports .......................................33

Appendix B. Forms of government ownership and private ownership ...............................35

Appendix C. US Airline Industry Consolidation within a Decade after 1978 Deregulation ....37

Vancouver/Hong Kong, September 2008 



\begin{abstract}
This paper examines revenue structure, regulation, and market power of airports, and how they affect airport's services to airlines and influence the form of vertical relationship between airport and airlines, and thus, eventually on competition in airline markets. In addition, we also examine the competitive consequences of common ownership, coordination or alliance among multiple airports in a region.
\end{abstract}

The key findings are:

- Concession revenues are of increasing importance to airports. The positive externality of air traffic on the demand for non-aeronautical services, along with competition among both airlines and airports, induces a vertical cooperation between airports and the dominant carrier at the airport.

- Airports have substantial market power due to the low price elasticity of their aeronautical services. However, such airports' market power is moderated by competition in both the airline and airport markets.

- There are benefits for both airports and airlines from entering into long term relationships. Airports can obtain financial support and secure business volume, which are important for daily operation as well as for long term expansion. Airlines can secure key airport facilities on favorable terms, essential for making long term commitments/investment at an airport. This along with the positive externality of the demand for airport's aeronautical services on commercial services provides incentives for the airport and the dominant carrier to strike exclusive deals, harming competition in the downstream airline market if unchecked. Such airport dominance allows an airline to obtain a substantial hub premium. On the other hand, cooperation between a hub airport and the dominant carrier may enhance the competition between airline networks formed by different airport-dominant carrier combinations. In other words, airport-airline coordination or alliance is a doubleedged sword for downstream airline competition, there is a need for careful further examination on the issue in order to design an effective regulatory oversight.

The issue of cooperation or alliance between two or more hub airports in a region needs more careful analysis because, while cooperation and coordination may improve customer service and efficiency, it is also likely to reduce competition not only between airports in the region but also between carriers in the downstream airline market. 


\section{INTRODUCTION}

In recent years, airports have been under growing pressure to be more financially selfsufficient and less reliant on government support. Many airports around the world have been commercialized and/or privatized so that airports are operated more like a business (Carney and Mew, 2003; IATA, 1997). Most countries have created regulatory agencies separately from airport operators. These changes introduced strong incentives for airport managers to increase revenue and reduce costs. The changing objective and strategy of airports, together with the evolving regulatory policies and governance structures influence airports' performance and their services to airlines. These changes are posing new challenges to airport managers and regulation system. In order to design a proper regulatory system, it is important to examine the determinant factors of airport performance, and the effects on the competition in downstream airline markets.

This paper seeks contributions in the following two areas: First, we review the key determinant factors for airport performance, and how they affect airport pricing and services to airlines. The issues reviewed include revenue structure, market power and regulatory regimes on airports. We then examine how airport services and business strategies influence competition in the downstream airline market, and the interactive effects between airline-airport vertical relations and the horizontal competition in airline and airport markets.

This paper is organized as follows: In Section 2, we study the revenue structure of airports, and its interactive effects with regulatory regime. This allows us to study airport pricing and services to airlines which affect airline performance. Section 3 discusses sources of airport market power, and how such market power is affected by the types of airlines using the airport, as well as by the airline and airport market structures. Section 4 examines evidence on airline hub premium, and how the existence of high hub premium may promote cooperative relations between a dominant airline and the airport. Section 5 reviews the alternative types of vertical relations between airlines and airports, and how they influence competition in the airline and airport markets. The last section concludes and summarizes the paper. 
Figure 1. Percentage of Non-aeronautical Revenue , 2006

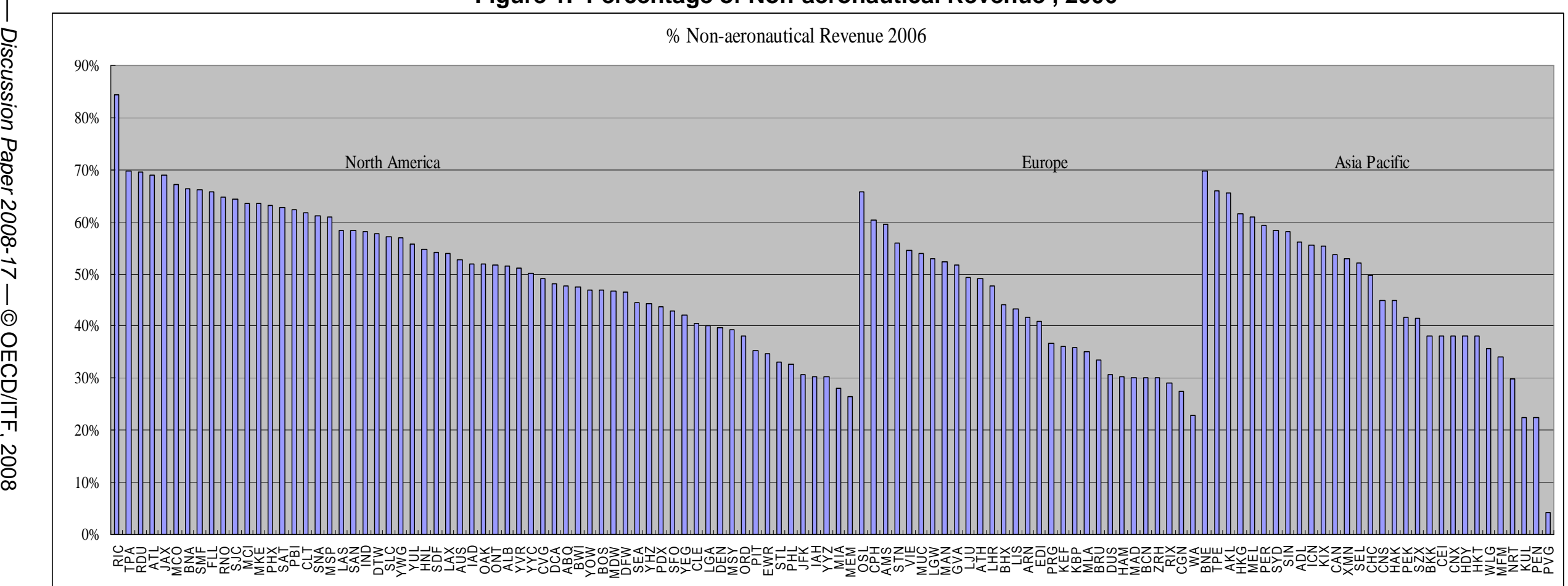

Source: The Air Transport Research Society (ATRS, 2006) 


\section{AIRPORT REVENUE STRUCTURE, REGULATION AND PRICING}

An airport derives its revenues from two sources: charges for aeronautical services such as aircraft landing (take-off) fees, aircraft parking and taxiway charges, passenger terminal and facility charges, etc, and the revenue from non-aeronautical sources such as concessions and other commercial services, car parking, office rentals, and other income from airport buildings and development of airport lands. As aeronautical charges are usually regulated, airports rely on commercial and other non-aeronautical services to bring in an increasing portion of their total revenues. For example, the Air Transport Research Society' global airport performance benchmarking project (ATRS, 2006) reports that most of the major airports around the world generate anywhere between $45 \%$ and $80 \%$ of their total revenues from non-aeronautical services, a major portion of which is concession revenue.

The unsatisfactory outcome of deregulation/light-handed regulation in New Zealand and Australia is likely due to the lack of competition among airports. In these two countries, population is concentrated around several major cities, with airports separated by long distances. The fact that Virgin Blue enters into expensive litigation with airports indicates that the carrier, despite being the second largest airline in Australia, has very limited countervailing power. As Forsyth (2006) points out, "there is no viable alternative airport within $150 \mathrm{~km}$ - the airline simply has no alternatives". Zhang and Zhang (2003) and Oum, Zhang and Zhang (2004) have shown that the presence of concession revenue does alleviate an airport's incentive to increase aeronautical service charges. However, Oum, Zhang and Zhang also concluded that an unregulated profit-maximizing airport, when not under competitive pressure from other airports, would have incentive to charge a price higher than the socially optimal level, and even higher than the price that publicly owned airport under breakeven financial performance requirement would charge. These findings do not necessarily reject Starkie's (2001) conclusion as he considered mainly the cases of Western European cities, where many airports compete with each other for airlines' business as well as competing with high-speed passenger railways. Instead, our investigation in the following section will show that the effects of an airport's concession revenue on airside service pricing are moderated by airline market structure, competition among airports as well as the vertical relationships between airline(s) and airport(s).

The form of regulation influences pricing behavior and performance of an airport significantly. Although various forms of airport regulations have been adopted by different countries around the world, the most widely used regulatory regimes are: (a) single-till pricecap regulation, (2) Dual-till price-cap regulation, (c) Rate of return regulation, and (d) lighthanded regulation (usually price and performance monitoring along with threat of regulation). A detailed discussion on the application of these regulations in various countries is available in appendix $A$.

Many studies have compared the performance of these regulatory regimes. A key issue in the debates on airport regulation has been on the merits of single-till versus dual-till price cap regulation. The advantages and disadvantages of each approach are discussed in 
Starkie and Yarrow (2000), Australian Productivity Commission (2002), UK CAA (2000 and 2003), and Niemeier (2002). Beesley (1999) questioned the appropriateness of single-till regulation. He argued that regulation should concentrate on activities that are characterized by a natural monopoly, and therefore, should not involve commercial activities. At the same time, since he doubts that it is possible to isolate the aeronautical activities from other airport activities, he generally rejects the applicability of price cap regulation on airports. Starkie and Yarrow (2000) suggest that the adoption of the single-till approach results in inefficiencies at capacity constrained airports, because non-aeronautical revenues keep aeronautical charges at a low level, and subsequently excess demand is artificially stimulated. They propose that a better outcome would be for aeronautical charges to be set at the level that provides a clear signal to enable resources to be efficiently allocated. Lu and Pagliari (2004) argue that the dual-till approach is desirable when an airport's aeronautical capacity is fully or over-utilized, while the single-till approach is preferable in the presence of excess capacity. In principle, under the dual-till system, the possible (excess) profits earned by airports from non-aeronautical services can be utilized to expand capacity and improve service quality. However, there is no easy answer to how to provide incentives for airports to do so. Czerny (2006) shows that an unregulated airport with excess capacity would tend to reduce charges for commercial services and raise aeronautical charges.. The intuition is that price elasticity of demand for commercial services higher than the price elasticity of the demand for airside services. Czerny further points out that single-till regulation dominates dual-till regulation at non-congested airports, in the sense that single-till regulation comes closer to maximizing welfare than dual-till regulation.

Overall, single till regulation appears to be superior to other regimes in terms of setting appropriate prices. The notion of regulating only the monopoly services (aviation services) is appealing in theory. However, dual-till regulation ignores the economies of scope for airports in providing aviation and concession services jointly. More importantly, dual till regulation does not internalize the demand complementarity between aviation and commercial services. As airlines who bring passengers to the airport may not benefit from directly from the concession sales, they may ignore such positive demand externality in their decisions. On the other hand, under a single till regulation, concession revenue may be used to crosssubsidize aeronautical charges.

For congested airports, Starkie and Yarrow's (2000) recommendation of dual-till regulation appears to be reasonable. However, the best remedy for capacity utilization may be peak-load pricing, or some sort of congestion pricing of the facilities such as slots, checking counter and bridges etc. The extra revenue generated from such a pricing may be used for capacity investments. In practice, however, such policy changes may be difficult due to influence of vested interests. ${ }^{1}$

While firms under rate-of-return regulation tend to over-capitalize their asset bases (Averch-Johnson effect ) a major problem with price-cap regulation, either single till or dual till, is that airports in the long run tend to under-invest in airport capacity. Oum, Zhang and Zhang (2004), using a econometric analysis of the ATRS (Air Transport Research Society) global airport efficiency benchmarking data, conclude that after controlling for the effects of factors beyond management control, airports under price-cap regulation tend to under-invest on capacity. 
Although all regulatory schemes discussed may be applied to any airport, actual regulation and intervention tend to be less strict nor explicit for government owned and operated airports. ${ }^{2}$ For example, many airports in the United States are owned by municipal governments and are operated by the city aviation departments. In principle, the Federal Aviation Act requires that airside fees cover only the costs associated with providing aeronautical services. The Federal Aviation Administration (FAA) was awarded the power to regulate the prices of U.S. airports. In practice, however, FAA has rarely exercised these powers as there is little to be gained by regulating a government undertaking which operates as a not-for-profit entity, lacking incentives to set unfair prices (Graham, 2004).

While an airport's aeronautical charges become an input price to airlines, the effect of airport capacity is a more complex matter. A capacity shortage will lead to airport congestion, implying a reduction of service quality to all carriers and passengers. On the other hand, capacity constraints could have differential impacts on different airlines using the same airport. A dominant carrier at an airport usually controls a significant proportion of key resources such as landing slots, check-in counters and gates. Capacity shortage at the airport may help the dominant firm to keep potential competitors out of the market. Therefore, it is not clear from the current literature as to what is the best way of allocating such precious resources, especially between incumbents and entrant airlines.

Airport pricing and services directly influence the performances of airlines. Our review of the revenue structure, regulatory regimes and pricing behavior of airports suggests the following:

- Concession and other non-aeronautical revenues are of increasing importance to airports. The positive externality effects of the demand for aviation services on the demand for commercial services reduces an airport's incentive to exploit its market power, and set high aeronautical charges. However, absent competitive pressure and explicit regulation, airports will increase their aviation service charges above the social optimal level, given the very low price elasticity of the demand for airport services.

- The regulatory and governance structure of airports is very complex and diverse. Single-till price-cap regulation appears to perform better than other approaches as it provides incentives for an airport to internalize the demand complementarity between aviation services and commercial services. However, in the long run, airports under price cap regulation tend to under-invest in capacity expansion. This may increase congestion and thus reduce service quality, as well as providing more opportunities for a dominant airline to prevent competitive entry.

- The actual pricing and performance of an airport are subject to a combined effect of many factors, some of which are beyond management control. Therefore, it is important to identify those true determinant factors in order make proper policy choice.

Another issue not addressed in the literature on airport regulation is the effect of the timing of changes in the regulatory regime. Suppose a country changes regulation of a privatized airport from single-till to dual-till price-cap regulation after the airport has already been privatized. Then it would create windfall gains for the owners of the airport, because theoretically the value of the airport will increase by the present value of the stream of increased future profits from the non-aeronautical business. Such a windfall gain would create inefficiency. But, if the decision on dual-till price cap regulation is made at the time 
the airport is privatized, then the future airport owners should not be able to make a windfall gain because the bid prices on the airport would reflect a larger amount of the future profits to be made from non-aeronautical services under the dual-till than under the single-till price cap regulation.

\section{AIRPORT MARKET POWER}

In the past, most airports were owned and operated by government branches, public sector agencies or corporations, probably because airports were regarded as a natural monopoly characterized by substantial economies of scale. Such a belief has now been disputed widely. Doganis (1992) states that economies of scale are probably exhausted at an annual output of about three million passengers. Jeong (2005) shows empirically that a constant returns to scale sets in at US airports at about three to five million passengers. Starkie (2001) even suggested that an airport's long run unit cost may be an increasing function of output. ${ }^{3}$ Since the natural monopoly argument for economic regulation may not hold in the case of airports, their market power is likely to come from the fact that it takes several decades to plan, environmentallyreview, and construct a new airport especially near a major metropolitan area. The rapid growth of air traffic often creates capacity shortage, which in turn gives airport pricing power.

Major airports have substantial market power for their airside services, because the price elasticity of the demand for airside services is very low since airport charges account for a relatively small portion of an airline's total cost. Gillen, Oum and Tretheway (1988) conclude that the price elasticity ranges between -0.01 and -0.1 depending on aircraft size/payload. This implies that airports can increase their aeronautical charges substantially without losing much traffic. Therefore, in the absence of regulation, a profit maximizing airport may be able to even double its aeronautical charges without losing much traffic (Fu, Lijesen, and Oum, 2006). However, the actual market power of an airport depends largely on the following factors:

- Airport capacity available in the region as compared to the rising demand for the capacity

- Airline market structure and competition at the airport and in the region;

- Share of Connecting Passengers;

- Inter-modal competition, especially between airlines and high speed rail;

- The extent and nature of competition with other airports, whose traffic catchments areas overlap significantly with the airport under consideration.

\subsection{Airport Capacity and Demand for that Capacity}

In a majority of the major metropolitan areas in Europe, U.S., and Asia, current capacity and future expansion plans are generally not sufficient to meet the rising demand for capacity since air passenger and freight transport demands increase at the average rates of 4-5\% and 5-6\% per year, respectively. Congested airports have an even greater incentive to 
raise airside prices since a reduction in traffic would lead to service quality improvement. Naturally these factors increase the market power of most airports in major metropolitan regions.

\subsection{Low Cost Carrier Airports}

On average, the average per-seat cost of EasyJet was $£ 40.48$ during the first half of 2008. Airport and ground handling costs added up to $£ 11.14$, more than $25 \%$ of the total cost. ${ }^{4}$ Clearly, LCCs specializing on short-haul markets will be far more sensitive to airport charges. Also, since LCCs utilize point-to-point networks without doing connecting services, it is less costly for them to switch airports if things do not work out with an airport. This reduces the market power of airports. Since LCC airports attempt to attract passengers in order to capitalize on the positive externality of air traffic on commercial services, LCC(s) has substantial bargaining power in negotiating fees with these airports.

Since major LCCs tend to have wider catchment areas than Full Service Airlines (FSAs), their choice of an airport in a region is quite flexible, and as such, can be largely influenced by the deals on aeronautical charges and what they can extract from the airport and/or the community, in exchange for bringing new business to the airport and community. For example, after the cold war, many military airports in Western Europe were commercialized. This introduced competition among airports whose catchment areas overlap. On the other hand, Ryanair and EasyJet have emerged as the two dominant LCCs in Europe. This allows them to negotiate good deals with competing airports. Ryanair paid, on average, $\$ 1$ or less per passenger to eight provincial UK airports during the $1998-2000$ period when the average aeronautical revenue at major airports in Europe were more than $\$ 8$ per passenger (Barrett, 2004). Furthermore, these LCCs were able to use their market power (as a big buyer) even to attract subsidies from airports. The European Commission have opened investigations on the possible state subsidy offered to EasyJet and Ryanair by some airports such as Belgium's Charleroi airport, Berlin Schoenefeld and Luebeck Blankensee airports in Germany, and Tampere Pirkkala in Finland. In the United States, some community airports heavily depend on a couple of Full Service Airlines (FSA) to link their airports to major carriers' hubs. In such case, airports offer favorable prices to these carriers to ensure connectivity to major airline networks.

\subsection{Airline market structure and competition.}

Since a primary hub airport for full service airlines provides very different services compared to a secondary airport targeting LCC services, ${ }^{5}$ the substitution effects between these airports, such as the case of Heathrow and Luton airports in the London area, are not as strong as the case when similar airports compete each other.

The market power of even a monopoly airport would be curtailed when one airline gets to dominate this airport. The dominant carrier can turn the airport-airline relation into one of bilateral-monopoly (monopoly-monpsony). Each side, namely the dominant airline and the airport, commands market power. In such case, the negotiated outcome between equally powered buyer and seller is usually socially efficient. The market outcome dictated by one dominant party (airport or airline) is inefficient. 
In reality, it is more likely that a monopoly airport may take advantage of the hub carrier's inability to move away from a natural hub airport. It is difficult and expensive for an FSA to move away from existing hubs. The UK Office of Fair Trading (OFT 2007) states "Carriers offering extensive long haul services, particularly those serving the US market, saw limited scope for substitution away from Heathrow" for the following reasons:

- Airlines in alliances, which schedule their flights to allow interconnection with other airlines in the alliance group, can not realistically switch airports independently of other alliance members: 21 of the top 30 airlines (by airport revenue) at Heathrow are members of Star Alliance, Oneworld Alliance or SkyTeam Alliance.

- Only Heathrow has the infrastructure to support hub activities.

- Heathrow is close to the large, wealthy population living along the M4 corridor, in north-west London and Buckinghamshire.

- In many circumstance, switching airports on international services is restricted by air services agreements (ASA).

As a result, a major airport tends to have more power over FSAs even if the airline is the dominant carrier at the airport. ${ }^{6}$ The monopoly power of an airport gets much larger when a major airport has no apparent hub carrier, with market shares at the airport being shared almost equally among a number of carriers. A good example is Los Angeles International Airport (LAX) which is almost equally shared among major US carriers.

\subsection{Share of Connecting Passengers}

When a high proportion of an airport's traffic is connecting traffic, monopoly power of both airlines and airports are limited on connecting traffic. This is because connecting passengers have choices to travel via different hubs. As a result they constrain the market power of airlines and airports. FedEx, for example, had established its Asian hub in Subic Bay. Since there is little local traffic, the carrier didn't experience much business loss when it decided to relocate the hub to Guang Zhou. Another extreme example is the Honolulu and Anchorage airports. Historically, these two airports had been major transit hubs since transPacific flights needed to do technical stops there. However, its importance quickly diminished when non-stop flights became possible. Because of this market power differential, we often find that it is considerably cheaper to fly, say, from Vancouver to Berlin via London than Vancouver to London. Similar examples on the pacific market would be that Vancouver to Shanghai via Tokyo is often considerably cheaper than Vancouver to Tokyo. Since both airlines and airports share a common objective of attracting more connecting passengers, the higher the proportion of connecting passengers (in a major airline's hub airport) the higher is the incentive for both the airport and airlines to cooperate with each other. This issue will be taken up further in the next section when we discuss airport-airline vertical relations.

\subsection{Inter-modal competition, especially between airlines and high speed rail}

The relationship between airlines and railway services can be competitive as well as complementary. It is likely that high speed rail (HSR) poses more competition to airlines in short-haul markets (e.g., Amsterdam-Paris; Brussels-Paris) than being complementary. As such, an increase in HSR services would reduce the market power of airlines and airports. 


\subsection{Competition among Airports in the Same Metropolitan Region}

Obviously, common ownership of several airports located in a metropolitan area or a region is likely to increase market power of those airports collectively. UK Competition Commission decided to order BAA plc. to divest Gatwick and Stansted, and either Edinburgh or Glasgow. This is consistent with its effort to reduce BAA airports' market power in these two regions. ${ }^{7}$ City of Chicago's plan to privatize Midway Airport (MDW) is certain to introduce competition with Chicago O'Hare airport (ORD), although the main motivation for this privatization came from the city's financial reasons. Since no substantial economy of scope has been observed for putting more than one airport in the same region under a common ownership, ${ }^{8}$ it appears more socially efficient to place each airport under separate ownership and management.

Presence of alternative airports under different ownerships can reduce airports' market power in the following way. Due to the competition among airports, the (firm-specific) price elasticity of demand faced by each airport, $\varepsilon_{i}$, is determined by the formula of $\varepsilon_{i}=\frac{\varepsilon}{S_{i}\left(1+v_{i}\right)}$, where $\varepsilon$ is the price elasticity of market demand for airport services in the region, $S_{i}$ is airport's $i$ 's market share, and $v_{i}$ is the conduct parameter which measures the nature of competition between airports. When $v_{i}$ takes values $0,-1$, and 1 , the competition among airports are of Cournot, Bertrand and collusive behavior types (Oum, Zhang and Zhang, 1993). Although empirical verification is necessary, the fact that airports compete with limited capacities suggests that they are likely to compete in Cournot fashion. ${ }^{9}$ This implies that when three symmetric airports compete with each other when the price elasticity of the market demand ranges -0.01 and -0.1 , each airport will face a firm-specific price elasticity in the range of -0.03 to -0.3 for their aeronautical services. This level of very low price elasticity would still allow these airports to increase prices significantly without losing much traffic.

When alternative airports are owned by the same (private) company, these airports will behave collusively such that $v_{i}$ approaches 1 , making airport specific elasticity approach close to the market elasticity. This allows airports under common ownership to retain market power. Therefore, the recent move by the UK Competition Commission on BAA's ownership of the London area and Scotland airports are pro-competitive. The common ownership and management of the three major airports in New York \& New Jersey metropolitan area (John F. Kennedy (JFK), Newark (EWR) and LaGuardia (LGA)) has caused similar problems for the US Department of Transportation (Oum, Yan and Yu, 2008).

An interesting and relevant question is, without government intervention, will adjacent airports under separate ownerships behave competitively, or they would rather to collude or to form alliance? If airports would prefer to work together with each other, even in an area being served by multiple independently owned airports, there may be needs for regulation. Studies on merger and alliance formation (Stigler, 1950; Salant et al. 1983; Rodrigues, 2001; Horn and Persson, 2001) suggest that the actual outcome depends on many factors, such as whether firms produce substitutes or complements, whether there are significant economies of scale in production, whether firms provide homogenous or differentiated 
services, conduct of competitors, structures of the upstream and downstream markets, etc. Without a detailed and country-specific study, it is difficult to predict competing airports' behavior. Other than the possible incentive of collusion, airports' alliance/ cooperation may lead to some synergy. Cooperation between two or more of nearby airports is likely to help allocate traffic more efficiently between those airports. Tokyo's Haneda airport focuses on intra-Japan flights while Narita airport focuses on international flights. Seoul's Gimpo (domestic) and Incheon (international) airports, and Shanghai's Hong Qiao (domestic) and Pudong (international) airports are similar cases. There is a recent proposal to link the Hong Kong International Airport with the Shen Zhen airport in southern China via a high speed rail for a similar division of flights. ${ }^{10}$

Therefore, the relations among airports in the same region need to be analyzed carefully. While coordination may improve customer services and operational efficiency of the combined airport group, it will reduce competition not only between airports in the region but also reduce competition in the downstream airline markets. In short, the strategic behavior of airlines will need to be considered when examining full impacts of allowing (or disallowing) competing airports to form alliance or merge with each other.

Airports derive two types of revenues: revenues from aeronautical charges and commercial and other non-aeronautical revenues. As most previous studies, we haven't discussed airports' market power on commercial operations since this is likely to be an

empirical question. Concession services at airports are imperfect substitutes to similar services offered in the city. Therefore, airport and concession service providers may have some market power. Certain developing countries allow airports to charge a premium for concession services, probably with the perception that those services are usually consumed by high-income and/or business travelers whose price elasticities tend to be low. Even in these markets, however, market power tends to be unsustainable in the long run. Prices have to be reduced in order to stimulate concession consumption. Shanghai Pudong International Airport has recently decided to reduce concession prices, in the hope that the airport can derive a higher proportion of revenues from non-aeronautical services in the future.

\section{AIRPORT DOMINANCE, AIRLINE HUB PREMIUM, AND IMPLICATIONS FOR AIRLINE-AIRPORT COOPERATION}

Since the deregulation of the US domestic market, airlines were given the freedom to optimize their route structures. As a result, hub-and-spoke networks have been expanded extensively by major network carriers. Such a change is accompanied by major shake-ups in the industry. Massive mergers, acquisitions, and liquidations occurred in the industry during the first 10 years after the 1978 deregulation as surviving major carriers were trying to strengthen their dominance in existing hubs and to expand continental market coverage. For example, many airlines based in Central and Eastern United States acquired carriers based in Western United States. ${ }^{11}$ 
Dominance at an airport allows a carrier to achieve substantially higher mark-up above costs. Such a benefit to the dominant carrier is referred as the "hub premium" in the literature. Borenstein (1989) studied airline pricing for local traffic to/from major US hubs in 1987. He found that dominance of major airports by one or two carriers would result in higher fares for consumers who want to fly to or from these airports. Such strongholds insulate the dominant carrier from competition ${ }^{12}$. This phenomenon has been confirmed by subsequent studies, albeit with varying magnitudes of hub premium ranging from well below $10 \%$ ((Dresner and Windle 1992; Morrison and Winston 1995; Lee and Prado 2005) to around 20\% (GAO 1989, 1990; Lijesen, Rietveld and Nijkamp 2004). Other than market power, alternative sources of hub premium, such as Frequent Flier Program (FFP), passenger mix and product differentiation (Lederman, 2008; Lee and Prado, 2005; Berry, 1990) are proposed over the years. US Department of Transportation (DOT, 2001), however, believes that these rationales commonly used to explain high fares in hub markets only apply if price competition is not present. ${ }^{13}$ It is the lack of price competition, not these rationales, that explain high prices at hub markets. DOT (2001) ${ }^{14}$ concluded that "from a consumer perspective, the primary disadvantage of network hubs is the level of market power that the hub carrier is capable of amassing and the higher prices consumers pay as a result. This stems from the fact that no airline with a similar cost structure can compete effectively at another airline's hub. DOT and others have reported on the prevalence of high fares paid by passengers at hub airports dominated by a network carrier; indeed, "no credible study concludes otherwise."

Regardless of the source of hub premium, such a benefit gives airlines strong incentive to dominate an airport. As shown in Table 1, except for Chicago O'Hare airport, virtually no major airlines share their hubs with others. ${ }^{15}$

Table 1. Share of Enplanements of the Dominant Carrier at Concentrated Hub Airports, 1978, 1993

\begin{tabular}{|l|c|c|c|c|}
\hline & \multicolumn{2}{|c|}{1978} & \multicolumn{2}{c|}{1993} \\
\hline Airport & Share & Carrier & Share & Carrier \\
\hline Atlanta & 49.7 & Delta & 83.5 & Delta \\
\hline Charlotte & 74.8 & Eastern & 94.6 & USAir \\
\hline Cincinnati & 35.1 & Delta & 89.8 & Delta \\
\hline Dayton & 35.3 & TWA & 40.5 & USAir \\
\hline Denver & 32.0 & United & 51.8 & United \\
\hline Detroit & 21.7 & American & 74.8 & Northwest \\
\hline Greensboro & 64.5 & Eastern & 44.9 & USAir \\
\hline Memphis & 42.2 & Delta & 76.3 & Northwest \\
\hline Minneapolis-St. & 31.7 & Northwest & 80.6 & Northwest \\
Paul & & & & \\
\hline Nashville & 28.5 & American & 69.8 & American \\
\hline Pittsburgh & 46.7 & Allegheny & 88.9 & USAir \\
\hline Raleigh-Durham & 74.2 & Eastern & 80.4 & American \\
\hline St. Louis & 39.4 & TAW & 60.4 & TWA \\
\hline Salt Lake City & 39.6 & Western & 71.4 & Delta \\
\hline Syracuse & 40.5 & Allegheny & 49.5 & USAir \\
\hline
\end{tabular}

Source: Morrison and Winston (1995). 
Meanwhile, while an airline often utilizes multiple hubs overall, they can not afford to have more than one hub in a region. Airneth (2005) observed that the closest distance between two major hubs in a successful dual-hub system is $900 \mathrm{~km}$, the case of Northwest's Minneapolis-St. Paul and Detroit. British Airways attempted to share hub functions of London-Heathrow airport with Gatwick airport, mainly to relieve congested Heathrow airport. However, they soon realized that it was not a winning game, and as a result, they decided to de-hub Gatwick (O'Connell, 2008). BA found that long-haul routes could be much more profitable by moving them to Heathrow, and duplicating a short-haul feed network from Gatwick was costly. It is an example of the failure of duplicating hubs in the same city. When Air France and KLM applied for merger, the Dutch Government was concerned since it might be of the merged airline's interest to reduce hub functions in Amsterdam (AMS). AMS is too close to Paris to be successful as a dual hub as shown in figure 2. In addition, Paris-CDG has much larger population base to support a Super-hub of the combined carrier. Therefore, Dutch government imposed the condition that the combined AF-KLM should maintain minimal of 42 major international key destinations from Amsterdam at least for the next 5 years. Consequently, the combined AF-KLM will not be able to make any major network restructuring involving international destinations or connecting services until 2010.

\section{Figure 2. Air France and KLM Merged Network: Paris and Amsterdam}

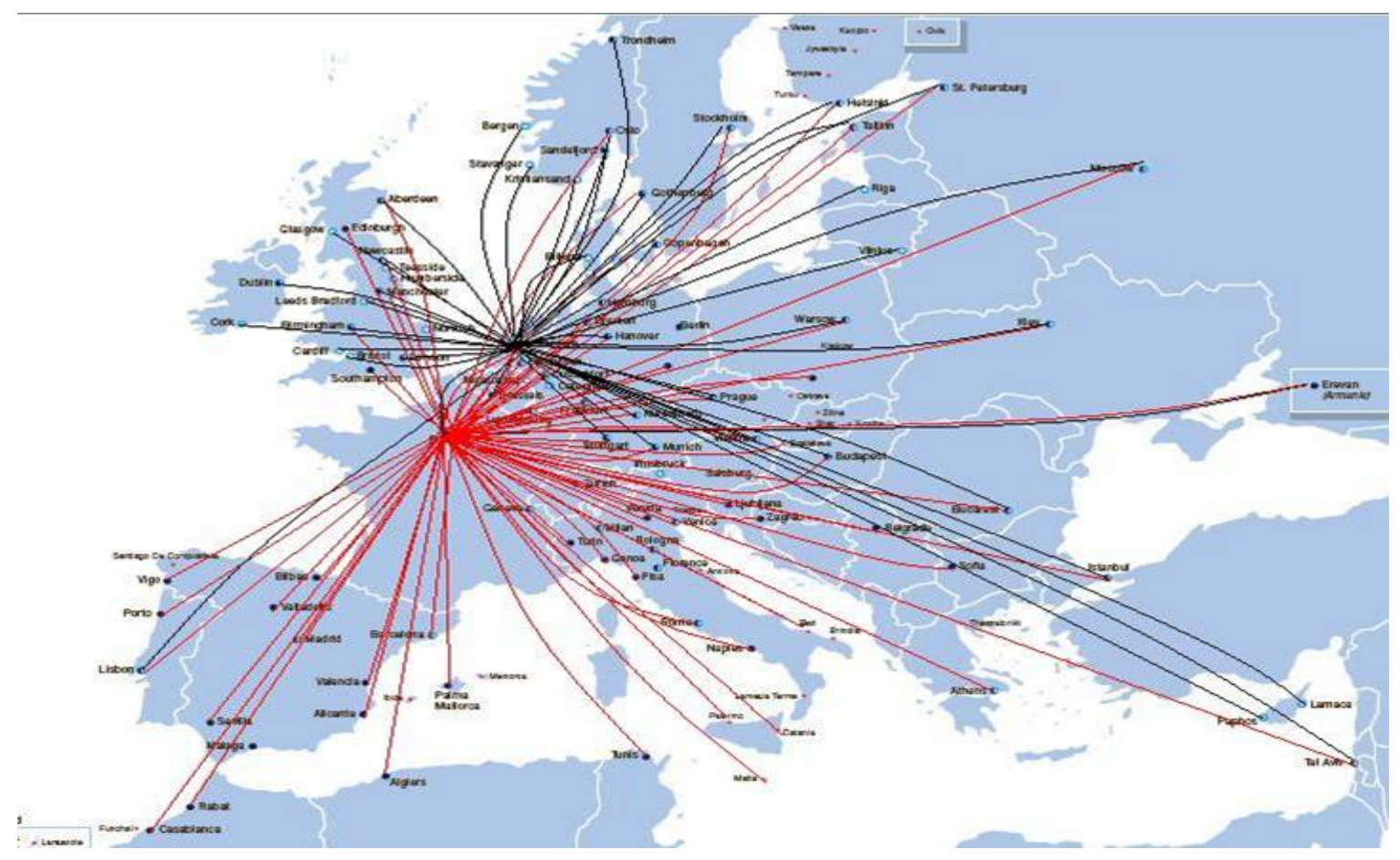

In summary, airport dominance allows a carrier to achieve hub premium and enjoy other related advantages. ${ }^{16}$ An airline prefers to have its own exclusive hub rather than to share a same airport with other carrier's hub function. While a carrier may set up an optimal multiple hub network for continental coverage, it can not afford to have more than one hub within a region. All of these factors indicate the following: 
- Network carriers will be competing in each of the major markets by setting up their hubs in different airports in each major market of the continent. These airports in each region will have substantially overlapping catchment areas. Some airports may be in the same city.

- The above provides a strong incentive for airports and their respective dominant airlines to cooperate with each other (vertical cooperation between airports and airlines) in order to compete successfully with other airport - hub airline combinations in the region.

\section{AIRPORT-AIRLINE VERTICAL RELATIONSHIP}

Despite some conflicting interests, especially with regard to aeronautical service charges, many airports have developed close relationships with airlines. The following types of relationship are often observed in practice:

- Signatory airlines. Many governments now require airports to be financially independent. Since those airports are free from government subsidy, many have chosen to work with airlines. Carriers who signa master use-and-lease agreement are awarded so-called signatory airline status. Those airlines become eventual guarantors of the airport's finance. In the case of 'residual' agreement, the signatory airlines pledge to cover the full cost of airport operations required for the airport to breakeven. The aeronautical service charges are determined by the 'residual cost' remained, after the revenues from non-signatory airlines and non-aviation sources have been deducted from the airport's total costs (debt service, interest, and operating expenses). In other cases, the main contribution from signatory airlines is service guarantee and usage commitment. This reduces uncertainty over future airport revenue, and thereby allows the airport to reduce financing costs when securing long term bank loans. In return, signatory airlines are given varying degrees of influence over airport planning and operations including slot allocation, terminal usage, capacity expansion projects, and exclusive or preferential facility usage.

- Airlines own or control airport facilities. Some airlines hold shares in airports or directly control airport facilities. For example, terminal 2 of Munich airport is a joint investment by the airport operating company FMG (60\%) and Lufthansa (40\%), the dominant airline at the airport. Lufthansa has also invested in Frankfurt airport, and holds a $29 \%$ share of Shanghai Pudong International Airport Cargo Terminal. By 2006, Thai Airways had invested over US\$400 million at the new Bangkok International Airport. ${ }^{17}$

- Long term usage contract. There are many cases where airlines and airports secure their cooperation via long term contracts. In recent years, the Low Cost Carriers (LCCs) have organized this type of long term contract with airports. Many 
secondary airports offer LCCs favorable usage terms in order to attract their traffic. However, once an airline incurs sunk costs in establishing its services out of the airport, the airline loses bargaining power because of the high cost of switching to a new base. Therefore, many LCCs choose to sign up long term contracts with airports in order to lock in the favorable terms. Long term contracts can also be helpful to airports. It encourages an airline to make long term investment to develop a more extensive network, securing airport traffic in the long run. Therefore, most airports are willing to sign such long term contracts. For example, in 2002 Melbourne airport and Virgin Blue reached a 10-year agreement for the airline to operate from the former Ansett/Southern Domestic Terminal.

- Airport revenue bonds. Many airports now choose to issue Special Facility Revenue Bonds (SFRB) to finance specific capital improvement programs ${ }^{18}$ (e.g., fuel farms, maintenance facilities, terminals, etc.). In these project financing arrangements, airports retain asset ownership but transfer the right for exclusive usage to the project sponsor under long-term lease agreements. The tax-exempt SFRBs are exclusively secured by the specific project's revenue stream, which is guaranteed by the project sponsor. The airport is without any obligation to SFRB bondholders in case of default. Therefore, much of the risk associated with the project is transferred from airports to airlines. In turn, SFRB gives airlines preferential or exclusive rights over key airport facilities.

\subsection{The costs and benefits of airport-airline integration}

The effects of vertical relationships between firms have been studied extensively in the economic literature. For example, vertical cooperation/integration may have positive efficiency effects such as the removal of double-marginalization (Tirole 1988), coordination of optimal production and inventory in supply chains (Cachon and Lariviere 2005, Dana and Spier 2001), etc. Vertical integration among firms may also bring negative effects on competition, such as market foreclosure and price squeeze (Greenhut and Hiroshi 1979, Salinger 1988, 1989, Schmalensee 1973), etc. However, vertical relations between airlines and airports have received little attention in the literature thus far. This is probably due to the fact price discrimination on aviation services is prohibited by the International Air Transport Association (IATA) rules. That is, an airport is required to charge all airlines the same price for identical services. Such a restriction, together with the historical public utility status of most airports, has often excluded airports from the lists of anti-trust investigation until the recent privatization wave. Nevertheless, as airports provide an essential input to airlines, such airline-airport cooperation, especially those offering exclusive deals to specific airlines, raises anticompetitive concerns.

In general, inter-firm relationships can be complex when one considers an upstream (airport) market and a downstream (airline) market jointly. Several studies model passenger travel choice over a region being served by multiple airports. In such a case, passengers choose a combination of airports and airlines, rather than airline services only (Ashford and Bencheman, 1987; Caves, Ndoh and Pietfield, 1991; Pels, Nijkamp and Rietveld, 2000, 2001, 2003b). Pels, Nijkamp and Rietveld (2001) point out that an airline faces two types of competitors: competitors operating from the same airport; and competitors operating from other airports. The airlines operating from the same airport may have conflicting interests as each tries to expand its market. But as opposed to the airlines operating from other airports, 
they may also have the same interest of making the airport attractive in order to attract more passengers to route their travel via the airport, and divide up those traffic among themselves.

While the above studies investigated competition among airline-airport combinations, there have not been much studies on the endogenous formation of airport-airline combination mechanism (i.e. the process during which airlines choose particular airports to serve, or the process during which airports attract particular airlines to establish home bases). As discussed in Section 4, airports do have incentives to ally with a particular airline. When an airport faces competition from other airports, either an adjacent airport sharing the same catchment area, or another major airport competing for connecting traffic, it is in each airport's interest to ally with one airline, normally the dominant carrier. The airport can secure its future traffic and revenue once a major carrier has decided to establish its hub there, a much needed commitment to an airport facing competitive and financial challenges. It does not help much for an airport to treat other carriers equally well, since the existence of a hub premium discourages airlines from sharing their own hubs with competitors.

On the other hand, airlines also have strong incentive to ally with an airport. The support and preferential treatments from airports allow a dominant carrier to secure the key resources needed for operation, and to gain competitive advantage over other carriers.

Thus, when there are competitive pressures in both the airline market and airport market, both airports and airlines have incentives to form vertical alliances. Such vertical cooperation, or possible tacit collusion, would further strengthen the dominant carriers' market power at the airport. This has raised some competitive concerns. In 2004, for instance, the European Commission ruled against the agreement between Belgium's Charleroi airport and Ryanair, claiming that the favorable terms offered by the airport constituted an illegal state aid.

Morrison and Winston (2000) and Dresner, Windle and Yao (2002), among others, found empirical evidence that a dominant airline's control over key airport facilities, such as slots and gates, is likely to impose significant entry barriers to other potential competitors. Gonenc and Nicoletti (2000) studied 102 air routes connecting 14 major international airports. They found in a large number of international airports, congestion phenomena are reported to exist and a single airline controls more than half of the available slots. This implies that dominant carriers are frequently in a position to use slot dominance at congested airports to close out competitors or raise costs for rivals costs on certain routes. As a result, few international routes are truly open to competition.

In the United States, the Charlotte/Douglas airport authority believed that it had benefited from having a single dominant carrier (US Airways) - the carrier was regarded as a "partner" of the airport. The U.S. Federal Aviation Administration (FAA), however, expressed concern that US Airways exercised too much control over airport facility and operations such as landing slot allocation and passenger terminal usage. The mayor of Charlotte appointed a task force to address the issues of airline competition. Additionally, the Aviation Department, pursuant to a directive from the City's Advisory Committee, hired a consultant to evaluate the competitive situation at Charlotte and to develop strategies for improvement (FAA 1999).

In general, FAA is concerned about an airport offering exclusive deals to a particular airline, because such special treatment may harm competition in downstream airline markets. Specifically, FAA is against airports' practice of giving exclusive or preferential 
facility usage to particular airlines. FAA suggests airports recover exclusive facilities for public usage. Airports are allowed to levy a Passenger Facility Charge (PFC) to finance nonexclusive facilities. In order to fully benefit from such revenue, large airports with a "dominant" carrier must submit to the U.S. Department of Transportation (DOT) a plan on how they intend to promote airport access, entry and competition (FAA, 1999). The requirement of submitting a competition plan was incorporated into the "Wendell $\mathrm{H}$. Ford Aviation Investment and Reform Act for the 21st Century", legislated in 2000. According to this Act, large and medium airports that exceed a certain threshold of concentration are required to submit competition plans.

With growing pressures for airports to improve their financial performances, new patterns of airport-airline relations emerge. For example, since concession revenue is increasingly important, airports and airlines now use various agreements to internalize the positive demand externality between aviation services and concession services. Since 2000, Tampa International Airport has been sharing concession revenues with its signatory airlines. On the airline side, Ryanair identified airport car parking as one of its major business opportunities and cooperates with the leading airport parking company BCP (Ryanair, 2005; Davy Securities, 2006). In its negotiation with some airports, Ryanair asked for sharing parking revenue as a condition to initiate services at these airports. ${ }^{19} \mathrm{Fu}$ and Zhang (2008) studied analytically various forms of concession revenue sharing arrangements. One of their findings is that when a carrier has significant competitive advantages over other carriers, a price regulated airport can enhance its own profit by cooperating with the dominant airline. This allows the dominant airline to strengthen its market power in terms of increased market share and profit at the expense of its competitors. The intuition is that concession revenue sharing provides competitive advantage to a sharing airline, who can internalize demand externality, and benefits from its competitors' output expansion in terms of getting more concession revenue. Since dominant carriers can exploits such competitive advantage more, an airport is more likely to work with them. Overall, Fu and Zhang (2008) found that cooperation between airlines and airports, such as the case of revenue sharing, may be a source of welfare gains. However, it may have negative effects on airline competition. In some cases, the airport and dominant airlines have incentives to collude each other at the expenses of other carriers.

In recent years, airlines and airports have developed various forms of vertical relations in order to reduce risk, internalize demand externalities and gain competitive advantages over other airlines/airports. Cooperation between an airport and an airline, however, may harm competition. The effects of these vertical relations are two-sided, which warrant further investigation. Imposing strict regulations at the current stage is likely to hinder innovation and reduce dynamic efficiency in the long run. Therefore, probably the best choice for regulators is to intervene only when there is clear evidence of negative effects. A simple and effective way to deter bad behaviors is to require disclosure of exclusive contracts between airports and airlines. Transparency and public scrutiny are cost-effective alternatives to "immature" regulation. 


\section{SUMMARY AND CONCLUSION}

In recent years, airports have been under growing pressure to be more financially selfsufficient and less reliant on government support. The process of privatization and commercialization strengthens managers' desire to enhance airport performance, while requiring a streamlined, cost effective regulatory system. Since airports provide essential inputs to airlines, performance in the airport market will have important impacts on the downstream airline market. In this paper, we attempted to achieve two main objectives: First, we study the key determinant factors for airport performance, and how they affect airport pricing and services to airlines. Three key factors are reviewed, namely revenue structure, regulatory regimes, and market power of airports. Secondly, this paper reviews how airport services, business strategies and airport-airline vertical relations influence downstream airline competition.

Our investigations lead to the following conclusions:

- $\quad$ Airport revenue structure: Concession and other non-aeronautical revenues are of increasing importance to airports. There is economy of scope to produce aeronautical and non-aviation services jointly. Airports expanding concession and other non-aeronautical service activities are likely to achieve higher efficiency and better financial performance, and thus, allow them to reduce aviation user charges to airlines and passengers. In addition, the positive externality of the demand for aviation services on the demand for concession services reduces an airport's incentive to exploit its market power vis-à-vis airlines. However, absent competitive pressure and explicit regulation, airports will still increase their service charges above socially optimal levels.

- $\quad$ Airport regulation: The regulatory and governance structure in the airport industry is very complex and diverse. In terms of pricing, single-till price regulation appears to perform better than the alternatives, since it mandates airports to internalize the demand complementarity between aviation services and commercial services. Dualtill regulation can be more efficient by pricing air services separately in congested airports. However, in the long run, airports under any kind of price cap regulation tend to under-invest in capacity. This may reduce airport service quality, and facilitate a dominant airline to close out competition from potential entrants.

- $\quad$ Airport market power: In general, airports possess substantial market power over aviation services due to the extremely low price elasticity. The availability of alternative airports will reduce airport market power, but not in the case of common ownership. However, the market power of airports is substantially reduced in the case of short haul markets served by LCCs, or airports dominated by one or only a few airlines. 
- $\quad$ Airport - airline vertical relation: There are benefits for both airports and airlines from entering into long term relationships: Airports can obtain financial support and secure business volume, which are important for daily operation as well as for long term expansion. For airlines, they can secure key airport facilities on favorable terms, which are essential conditions for them to make long term commitment/investment at an airport. This provides incentives for the airport and the dominant carrier to strike exclusive deals, harming competition in the downstream airline market if unchecked. Such a dominance of one airline at an airport allows the airline to obtain a substantial hub premium.

- Cooperation and competition between two or more airports in a region: Cooperation between two or more airports is likely to help allocate traffic more efficiently between those airports. This issue needs more careful analysis because while the cooperation and coordination may improve customer services and the operational efficiency of the airports, it is likely to reduce competition not only between airports in the region but also between carriers in the downstream airline markets.

In summary, our findings suggest that the airport industry and its relations with airlines are experiencing major changes, which have important implications for airport management and regulatory policies. While the performance of airports directly determines their pricing and services to airlines, there are also interactive impacts between the two markets as evidenced by the vertical relations between airlines and airports. Therefore, there is a need to recognize the upstream - downstream relations between airports and airlines when one evaluates airport performance, or designs regulatory policies for airports and airlines. 


\section{NOTES}

1. For example, the US Department of Transportation (DOT) announced its plans to auction some slots of the three airports in NY-NJ Metropolitan area, in the hope that this will encourage entry of competing airlines and generate revenue to upgrade air traffic control systems. However, this plan has received strong opposition from the airport management and the Ports Authority of New York and New Jersey, the owner of the airports, who threaten to file law suit to stop the Federal Government from selling "something it does not own". In reality, a resource allocation model must be in line with state laws as well as being consistent with economic intuition.

2. There are alternative forms of government ownership and control over airports. A brief summary is available in appendix $B$.

3. The majority of the empirical studies on airport cost functions can not be relied for measuring economies of scale because of one or more of the following problems: (a) ignores non-aeronautical services outputs which account for $40-80 \%$ of total revenues of an airport; (b) separate artificially airside services output from terminal services; and (c) use of unrealistically simple capital input calculation.

4. EasyJet 2008 Interim report, no breakdown of airport service charges and handling costs was available at http://www.easyjet.com/EN/Investor/investorrelations financialreports.html .

5. For a discussion of the different requirements for airport services by FSAs and LCCs, see Gillen and Morrison (2003)

6. One former chief executive of a major Canadian airport stated openly in an academic conference in United States that there is no need to consult with airlines when planning airport capacity. There is no need for airport management listen to what airlines say. This may be an extreme example, but it illustrates that major airports have market power over even the dominant hub airlines.

7. The UK's Office of Fair Trading (OFT 2007) pointed out that "Carriers offering extensive long haul services, particularly those serving the US market, saw limited scope for substitution away from Heathrow". Even after considering alternative remedies for BAA's jointly ownership in the London area, OFT (2007) believes that "Heathrow would retain market power due to its hub status (and possibly other factors including its size, reputation and good surface access from central London).

8. We have not seen any empirical estimates on the economies of scope for an agency or firm to operate multiple airports in a metropolitan region. However, it appears that the 
negative effects of monopoly power of an agency owning multiple airports in the region is likely to exceed whatever the positive effect on society of allowing a monopolist to operate multiple airports in a region.

9. Kreps and Scheinkman (1983) proved that if firms first make pre-commitment of quantity, and then compete with price, the equilibrium outcome will be equivalent to Counot competition.

10. There are five adjacent airports near Hong Kong: Hong Kong (HKG), Guang Zhou (CAN), Shen Zhen (SZX), Macau (MFM) and Zhuhai (ZUH). In 2006, Hong Kong Airport Authority (HKAA) acquired $55 \%$ of the Zhu Hai Airport for a price of US $\$ 24.75$ million HKAA's control over the two airports is achieved via the ownership of the Zhuhai-Hong Kong Airport Management Company Ltd, which a joint venture formed by HK Airport Authority and the state owner of Zhu Hai airport. The joint venture will manage and operate Zhu Hai airport for 20 years.

11. For example, Delta acquired Western Airlines in order to expand their market coverage in western United States and to secure Salt Lake City as its western hub while American Airlines strengthened its Dallas -Ft Worth hub and acquired Air California. US Air acquired Piedmont and Pacific Southwest. On the other hand, Northwest acquired Republic in order to increase dominance of its Minneapolis-St. Paul hub and surrounding markets. Appendix C summarizes the consolidation process of the US airline industry.

12. Borenstein (1989) found, ceteris parabus, a dominant airline on a route with a $70 \%$ share of the traffic might be able to charge from $2 \%$ to $12 \%$ higher prices than its rivals which only have $10 \%$ shares. Hub premium is even more evident for flights connecting two hubs of the same carriers. An airline with $50 \%$ of the traffic at each endpoint of a route is estimated to charge high-end prices about $12 \%$ above those of a competitor with $10 \%$ of the traffic at each endpoint.

13. DOT (2001) concludes that "In dominated hubs as a whole, 24.7 million passengers pay on average $41 \%$ more than do their counterparts flying in hub markets with low-fare competition."

14. http://ostpxweb.dot.gov/aviation/domestic-competition/hubpaper.pdf

15. AirTran maintain a hub at Atlanta, but its market power is not comparable to Delta, who has established its super-hub at the same airport.

16. Other researchers studied the effects of hub-and-spoke networks in general, and concluded that such a network would indeed allow hub carriers to price and compete more strategically (Spiller 1989, Berry 1990, Bittlingmayer 1990, Brueckner and Spiller 1991, Brueckner et al 1992, Zhang and Wei 1993, Oum et al. 1995, Zhang 1996, and Hendricks et al. 1997)

17. Many other airlines control or own airport facilities, especially in their domestic hubs. Qantas owns terminals in both Sydney airport and Melbourne airport. LAPA Airways holds minority share in Airport Aeropuertos Argentina. In 1994, a consortium of four 
international airlines (Air France, Japan Airlines, Korean Air, and Lufthansa) invested in terminal 1 of JFK International Airport in New York.

18. In general, there are three types of revenue bonds: general airport revenue bonds (GARBS), special facility revenue bonds (SFRBs), and PFC-backed bonds.

19. In other cases, revenue sharing is in effect when airlines hold shares in airports or directly control airport facilities. For example, terminal 2 of Munich airport has about 110 stores and restaurants. Profits generated from it, including those from the lease of areas for catering and retail, are shared by FMG and Lufthansa (Kuchinke and Sickmann, 2005). 


\section{REFERENCES}

AirNeth (2005), "Strategies of multi-hub airlines and the implications for national aviation policies," AirNeth Workshop Report, 2005.

Ashford, N. and Bencheman, M (1987), "Passengers' choice of airport: an application of the multinomial logit model," Transportation Research Record, 1147, National Research Council, Washington, DC.

ATRS (Air Transport Research Society) (2006), "The ATRS Airport Performance Benchmarking Report: Global Standards for Airport Excellence," 3 volume report, published by the Centre for Transportation Studies, University of British Columbia, Vancouver, British Columbia. July 2006. www.atrsworld.org.

Barrett, S. (2004), "How Do the Demand for Airport Services Differ between Full Service Carriers and Low-cost Carriers?," Journal of Air Transport Management, Vol. 10., pp.33-39.

Beesley, M.E. (1999), Airport Regulation, in Beesley, M.E. ed., Regulating Utilities: a New Era?, Institute of Economic Affairs, London.

Berry, S. (1990), "Airport presence as product differentiation," American Economic Review 80, pp. 394-399.

Bittlingmayer, G. (1990), "Efficiency and entry in a simple airline network," International Journal of Industrial Organization, 8, 245-57.

Borenstein, S (1989), "Hubs and High Fares: Dominance and Market Power in the U.S. Airline Industry," RAND Journal of Economics, Vol. 20, No. 3, pp. 344-365.

Brueckner, J. K. and Spiller, P.T. (1991), "Competition and Mergers in Airline Networks," International Journal of Industrial Organization, 9, 323-342.

Cachon, P.G. and Lariviere, M.A. (2005), "Supply chain coordination with revenue-sharing contracts: strengths and limitations," Management Science, 51(1), 30-44.

Carney, M. and Mew, K. (2003) "Airport governance reform: a strategic management perspective," Journal of Air Transport Management, 9, 221-232.

Caves R. E., Ndoh N. N. and Piefield D. E. (1991), "Route choice modeling applied to the choice between mature airports and emergent airports in their shadow," paper presented at the 31st RSA European Congress, Lisbon.

Czerny, A. I. (2006), "Price-Cap Regulation of Airports: Single-till versus Dual-till," Journal of Regulatory Economics, 30, 85-97. 
Dana, D.J. and Spier, K. (2001), "Revenue sharing and vertical control in the video rental industry," Journal of Industrial Economics, 3, 223-245.

Davy Securities Limited (2006), "Ryanair as a consumer growth company - inside the 21stcentury European travel phenomenon," Davy European Transport and Leisure, 28 March 2006.

Doganis, R. (1992), The Airport Business, Routledge, London.

DOT (U.S. Department of Transportation) (2001), Dominated hub fares, Domestic aviation competition series.

Dresner, M.E., Windle, R.J., (1992), "Airport dominance and yields in the U.S. airline industry," Logistics and Transportation Review, 28 (4), 319-339.

Dresner, M., Windle, R. and Yao, Y. (2002), "Airport Barriers to Entry in the US," Journal of Transport Economics and Policy, 36(2), pp. 389- 405.

FAA (U.S. Federal Aviation Administration) (1999), "Airport business practices and their impact on airline competition," FAA / OST Taskforce study.

Forsyth, P. (1997), "Price regulation of airports: Principles with Australian applications," Transportation Research E, 33, 297-309.

Forsyth, P. (2002a), "Privatization and regulation of Australian and New Zealand airports," Journal of Air Transport Management, 8, 19-28.

Forsyth, P. (2002b), "Regulation under stress: Developments in Australian airport policy," Journal of Air Transport Management, 9, 25-35.

Forsyth P. (2006), "Airport Policy in Australia and New Zealand: Privatisation, Light Handed Regulation and Performance," Paper for Conference "Comparative Political Economy and Infrastructure Performance: the Case of Airports", Madrid, September 18-19, 2006.

Fu, X., Lijesen, M. and Oum, T.H. (2006), "An Analysis of Airport Pricing and Regulation in the Presence of Competition between Full service Airlines and Low Cost Carrier," Journal of Transport Economics and Policy, Vol.40 (3). pp.425-447.

Fu, X. and Zhang, A. (2008), "Effects of Airport Concession Revenue Sharing on Competition and Social Welfare", proceedings of the ATRS 2008 conference in Athens.

GAO (U.S. General Accounting Office) (1989), "Barriers to Competition in the Airline Industry."

GAO (U.S. General Accounting Office) (1990), "Airline competition: industry operating and marketing practices limit market entry." 
Gillen, D. and Morrison, W (2003), "Bundling, integration and the delivered price of air travel: are low cost carriers full service competitors?," Journal of Air Transport Management 9 (2003), pp. 15-23.

Gillen, D., Oum, T.H. and Tretheway, M.W. (1988), "Airport Pricing Policies: An Application to Canadian Airports," The Proceedings of the (U.S.) Transportation Research Forum, 1988, pp.28-34.

Gonenc, R. and Nicoletti, G. (2000), "Regulation, Market Structure and Performance in Air Passenger Transportation," OECD Economics Department Working Papers.

Graham, A. (2004), "The Regulation of US Airports," in P. Forsyth, D.W. Gillen, A. Knorr, O.G. Mayer, H-M Niemeier, and D. Starkie, eds, The Economic Regulation of Airports, Ashgate Publishing Limited, Aldershot, England, 61-72.

Greenhut, M. and Hiroshi, O. (1979), "Vertical Integration of Successive Oligopolies," American Economic Review, vol. 60, pp. 137-141.

Hendricks, K., Piccione, M. and Tan, G. (1997), "Entry and exit in hub-spoke networks," RAND Journal of Economics, 28, 291-303.

Horn, H. and Persson, L. (2001), "Endogenous mergers in concentrated markets," International Journal of Industrial Organization, 19, pp.1213-1244.

International Air Transport Association (IATA) (1997) "IATA Policy on User Charges Aspects of the Commercialization of Airports and Air Traffic Service Entities," International Air Transport Association, Montreal.

Jeong, J.H. (2005), "An investigation of operating costs of airports: focus on the effects of output scale," Master Thesis, University of British Columbia, Vancouver, Canada.

Kreps, D. and Scheinkman, J. (1983), "Quantity Precommitment and Bertrand Competition Yield Cournot Outcomes," Bell Journal of Economics, Vol. 14(2), pp. 326-337.

Lederman, M. (2008), "Are Frequent Flyer Programs a Cause of the 'Hub Premium'?" Journal of Economics and Management Strategy, Vol. 17(1), pp.35-66.

Lee, D., and Prado, M. J. (2005), "The Impact of Passenger Mix on Reported "Hub Premiums" in the U.S. Airline Industry," Southern Economic Journal, 72, pp.372-396.

Lijesen M., Rietveld P. and Nijkamp P. (2001), "Hub premiums in European civil aviation," Transport Policy, Vol8, 3, pp.193-199.

Lu, C-C and Pagliari, R. I. (2004), "Evaluating the Potential Impact of Alternative Airport Pricing Approaches on Social Welfare," Transportation Research E, 40, 1-17.

Morrison, Steven and Winston, Clifford (1989), "Enhancing the Performance of the Deregulated Air Transportation System," Brookings Papers on Economic Activity. Microeconomics, Vol. 1989, (1989), pp. 61-123. 
Morrison, S. and Winston, C. (1995), The Evolution of the Airline Industry, The Brookings Institution.

Morrison, S. A. and Winston, C. (2000), The remaining role for government policy in the deregulated airline industry, Deregulation of Network Industries, Sam Peltzman and Clifford Winston, (eds.), The Brookings Institution, Washington, DC.

Niemeier, H.-M (2002), "Regulation of airports: the case of Hamburg airport-a view from the perspective of regional policy, Journal of Air Transport Management," 8 (1), 37-48

O'Connell, J. F., Guest Speaking (2008) to TRS 2008 Conference, "The impact of the new Open Skies' agreement for traffic between the EU and the US market".

Office of Fair Trading (OFT, 2007), BAA - The OFT's reference to the Competition Commission, www.competition-commission.org.uk/inquiries/ref2007/airports/pdf/ oft reference to the cc.pdf

Oum, T.H., Yan, J. and Yu, C. (2008). "Do Ownership Forms matter for Airport Efficiency: Results from Bayesian Estimation of Stochastic Cost Frontiers", J. of Urban Economics, forthcoming. http://dx.doi.org/10.1016/j.jue.2008.03.001

Oum, T. H., Yu, C., Fu, X. (2003), "A comparative analysis of productivity performance of the world's major airports: summary report of the ATRS global airport benchmarking research report-2002," Journal of Air Transport Management, 9, 285-297.

Oum, T.H., and Yu, C. (2004), "Measuring Airports' Operating Efficiency: A Summary of the 2003 ATRS Global Airport Benchmarking Report," Transportation Research E, 40, 515-532.

Oum, T.H., Zhang, A. and Zhang, Y. (1995), "Airline network rivalry," Canadian Journal of Economics, 95, pp. 836-857.

Oum, T. H., Zhang, A. and Zhang, Y. (1993), "Inter-Firm Rivalry and Firm-specific Price Elasticities in Deregulated Airline Markets," Journal of Transport Economics and Policy, 27, 171-92.

Oum, T.H., Zhang, A. and Zhang, Y. (2004), "Alternative forms of economic regulation and their efficiency implications for airports," Journal of Transport Economics and Policy, 28(2), 217-246.

Pels, E., Nijkamp, P., Rietveld, P. (2000), "Airport and airline competition for passengers departing from a large metropolitan area," Journal of Urban Economics, 48(1), 29-45.

Pels, E., Nijkamp, P., Rietveld, P. (2001), "Airport and airline choice in a multi-airport region: an empirical analysis for the San Francisco bay area," Regional Studies, 35, 1-9.

Pels E, Nijkamp P. and Rietveld P. (2003a), "Inefficiencies and scale economies of European airport operations," Transportation Research Part E, 39, pp.341-361. 
Pels, E., Nijkamp, P., Rietveld, P. (2003b), "Access to and competition between airports: a case study for the San Francisco Bay area," Transportation Research A, 37, 71-83.

Productivity Commission (2002), Price Regulation of Airport Services, Report No. 19, AusInfo, Canberra.

Rodrigues, V. (2001), "Endogenous Mergers and Market Structure," International Journal of Industrial Organization, 19, 1245-1261.

Salant, S.W., Switzer, S. and Reynolds, R.J. (1983), "Losses due to merger: The effects of an exogenous change in industry structure on Cournot-Nash equilibrium," Quarterly Journal of Economics, 98, 185-199.

Salinger, Michael (1988), "Vertical Mergers and Market Foreclosure," Quarterly Journal of Economics, vol. 103, pp. 345-356.

Salinger, Michael (1989), "The Meaning of 'Upstream' and 'Downstream' and the Implications for Modeling Vertical Mergers," Journal of Industrial Economics, vol. 37, no. 4, pp. 373-387.

Schmalensee, R. (1973), "A Note on the Theory of Vertical Integration," Journal of Political Economy, vol. 81, pp. 442-449.

Sarkis, J. (2000), "An analysis of the operational efficiency of major airports in the United States," Journal of Operations Management, 18, 335-351.

Spiller, P. T. (1989), "Pricing of Hub-and-Spoke Networks," Economics Letters, 30, 165-169.

Starkie, D. (2001), "Reforming UK airport regulation," Journal of Transport Economics and Policy, 35,119 -135.

Starkie, D. and Yarrow, G. (2000), The Single-till Approach to the Price Regulation of Airports, www.caaerg.co.uk

Stigler, G.J. (1950), "Monopoly and oligopoly by merger," American Economic Review, 40, 23-34.

Tirole, J. (1988), The Theory of Industrial Organization, The MIT Press, Cambridge, Massachusetts.

UK Civil Aviation Authority (CAA) (2000), The Single Till and the Dual Till Approach to the Price Regulation of Airports, CAA Decisions (December), London.

UK Civil Aviation Authority (CAA) (2003), Economic Regulation of BAA London Airports, CAA Decisions (February), London.

Zhang A. (1996), "An Analysis of Fortress Hubs in Network-based Markets," Journal of Transport Economics and Policy, Vol. 30, pp. 293-308. 
Zhang A. and X. Wei (1993), "Competition in Airline Networks: The Case of Constant Elasticity Demands," Economics Letters, 42, 253-259.

Zhang, A. and Zhang, Y. (2003), "Airport charges and capacity expansion: effects of concessions and privatization," Journal of Urban Economics, 53, 54-75. 


\section{APPENDIX A. ALTERNATIVE FORMS OF ECONOMIC REGULATION OF AIRPORTS}

Single-till Price regulation: Price regulation usually takes the form of a price-cap applied to revenues deriving from airport charges per passenger. With single till price regulation, price cap is applied only to aviation services. However, both aeronautical and commercial revenues and costs are considered in determining the level of aeronautical charges. There is, therefore, a cross subsidy for aeronautical services with revenues arising from commercial activities.

The single-till principle was recommended by ICAO and has been widely used in Europe, including UK, Austria, France, Ireland, Norway, Spain, Portugal, Sweden, and most airports in Germany. In the UK, the Civil Aviation Authority (CAA) sets price caps on airport charges every five years at airports designated by the Secretary of State, using the RPI-X formula. Price cap regulation outside the UK is generally based on the CPI - X formula, and the regulatory review periods vary between 3 to 5 years.

With single till price regulation, air carriers would share part of the airport's commercial revenues by paying lower aeronautical charges because of the cross-subsidization of aeronautical services from commercial services. This is a major reason why single-till pricecap regulations are widely supported by airlines. However, this leaves aeronautical service prices below provision costs, which poses a problem, especially at a congested airport.

Dual-till Price Regulation separates aeronautical functions from non-aeronautical ones. It determines the level of aeronautical charges by considering aeronautical revenues and costs only. Consequently, the corresponding asset base includes aeronautical assets only. Aeronautical charges will be likely to be set at a higher level under a dual-till approach, especially at a congested airport, than under a single-till approach where cross-subsidization from non-aeronautical revenues will help off-set some of the costs of the aeronautical services.

The price cap for Hamburg Airport was the first to be set on a dual-till in 2000 on the argument that regulation should be confined to the monopolistic bottleneck and incentives for developing the non-aviation business should not be stifled (Niemeier, 2002). Other airports adopted dual-till regulation are Frankfurt, Copenhagen, Malta and Budapest.

Rate of Return regulation benchmark the profitability of regulated activities to the average of reference airports or businesses. It tends to be complex, unresponsive and expensive to administer due to the lengthy regulatory hearings involved. Currently, it is used in Belgium and Netherlands.

It should be noted that the operator of Amsterdam Airport, Schiphol Group's shares are held by the State of the Netherlands, the City of Amsterdam and the City of Rotterdam. However, Schiphol Group is a financially independent, commercial company that is subject to corporation tax effective from 1 January 2002. The fact that Schiphol Group is government owned may alleviate the complexity and interests conflicts in implementing the rate-of-return regulation. 
Price Monitoring and Threat of Regulation is currently implemented in Australia and New Zealand. The regulators use a trigger or "grim strategy" regulation where a light-handed form of regulation is used until the subject firm sets prices or earns profits or reduces quality beyond some point and thus, triggers a long-term commitment to intruding regulation.

Australia initially imposed dual-till price cap regulation on all privatized airports. Primarily based on the recommendation of the Productivity Commission (2001), on 1 July, 2002 the government ended the price-cap regulation on all privatized airports for a period of five years (Fu, Lijesen and Oum, 2006). The larger airports, including Sydney, are now subject to price monitoring, and the smaller airports are not subject to any controls.

New Zealand does not subject its privatized airports to formal price regulation. Airlines have been very critical of the pricing policies at some regulated airports (Productivity Commission, 2006, Bisignani, 2006).

In UK, a system of light-handed regulation applies to airports at which annual turnover has exceeded $£ 1$ million pounds in two of the previous three financial years, excluding those airports designated for price cap regulation in London and Scotland. 


\section{APPENDIX B. FORMS OF GOVERNMENT OWNERSHIP AND PRIVATE OWNERSHIP}

In practice, following forms of government ownership and control have been most frequently observed in the airport industry:

- Owned and operated by national government - as both regulator and operator Examples: Spain (Aeropuertos Españoles y Navegación Aérea (AENA) is in charge of 48 airports (McCarthy and McDonnell, 2006) as well as the Air Traffic Control system.); Singapore (Singapore Changi Airport is owned and operated by the Civil Aviation Authority of Singapore (CAAS). CAAS acts as both the regulator and operator of Changi Airport.)

- Owned and operated by national government - Separate regulator and operator

Examples: Finland (regulator: Finnish Civil Aviation Authority; Operator: the former Finnish Civil Aviation Administration, renamed as Finavia); Sweden (Regulator: Swedish Civil Aviation Authority; Operator: Luftfartsverket - LFV Group)

\section{- Owned and operated by local government departments}

Examples: In the United States, many airports are owned by the local governments. In general, these airports rely heavily on private sector contracting as well as airline investments in the operation and financing of infrastructure. FAA has the authority to regulate at federal level.

\section{- $100 \%$ Government Corporation}

Examples: The Norwegian state through the Ministry of Transport and Communications controls $100 \%$ of the share of Avinor, which owns and operates 46 airports in Norway. Hong Kong International Airport is operated by Airport Authority Hong Kong (AA), wholly owned by the Government of the Hong Kong Special Administrative Region (HKSAR). The authority has, for all practical purposes, operated as a government corporation (Cheung, 2006). Other examples include the Incheon International Airport Corporation (IIAC) and Dublin Airport Authority (DAA).

\section{- Not-for-Profit Airport Authority}

Example: Canada and the US. The term "airport authority" is not clearly defined. In Canada, it refers to a not-for-profit private sector entity that operates airports under long term lease contract. In the United States, in generally is used to mean a quasi-government agency that operates airports at arm's length from a municipal or county government (Tretheway, 2001).

\section{- Multi--government ownership}

Example: Germany, New Zealand, Japan, and the Netherlands. Munich Airport is operated by Flughafen München $\mathrm{GmbH}$ that is jointly owned by the Free State of Bavaria (51\%), the Federal Republic of Germany (26\%), and the city of Munich (23\%). 
In recent years, some countries have fully / partially privatized their airports. An incomplete list of these airports is provided below:

- Fully-privatized:

Example: Most airports in UK, except the Manchester Group, Newcastle (49\% private interest) and Luton (30-years concession contract), Australia (most of the medium to large airports are privately owned, smaller airports are owned by local governments), Italy (Rome). Fully privatized airports refer to those where governments no longer have any ownership interest in the airports. The airports may be fully traded on the stock markets or fully owned by a private group or consortium.

- Mixed ownership with private majority:

Example: Belgium, Denmark, Austria, New Zealand (Wellington and Auckland), Switzerland (Zurich). In many countries, full privatization is restricted as the former public owners (i.e. national governments) want to secure certain public interests to be guaranteed by a golden share or a wide ownership clause.

- Mixed ownership with government majority:

Example: Germany (Frankfurt, Hamburg), France (de Gaulle and Orly), China (Beijing and Shanghai), Japan (Kansai International). In most cases, governments retain a majority stake in privatizing their airports. This is the most prevalent ownership form outside UK, Australia, and New Zealand. 


\section{APPENDIX C. US AIRLINE INDUSTRY CONSOLIDATION WITHIN A DECADE AFTER 1978 DEREGULATION}

\begin{tabular}{|c|c|c|}
\hline Year & Carriers & Status ${ }^{\mathrm{a}}$ \\
\hline 1987 & $\begin{array}{l}\text { USAir-Piedmont } \\
\text { American-Air California } \\
\text { USAir-Pacific Southwest }\end{array}$ & $\begin{array}{l}\text { Approved by DOT } \\
\text { Approved by DOT } \\
\text { Approved by DOT }\end{array}$ \\
\hline 1986 & $\begin{array}{l}\text { Delta-Western } \\
\text { Texas Air-People Express } \\
\text { Texas Air-Eastern } \\
\text { Trans World Airlines-Ozark } \\
\text { Northwest-Republic }\end{array}$ & $\begin{array}{l}\text { Approved by DOT } \\
\text { Not-anticompetitive finding by DOJ } \\
\text { Approved by DOT } \\
\text { Approved by DOT after sale } \\
\text { of slots to Pan Am Shuttle } \\
\text { Opposed by DOJ } \\
\text { Approved by DOT } \\
\text { Opposed by DOJ } \\
\text { Approved by DOT }\end{array}$ \\
\hline 1985 & United-Pan American ${ }^{\mathrm{b}}$ & $\begin{array}{l}\text { Opposed by DOJ } \\
\text { Approved by DOT }\end{array}$ \\
\hline 1982 & Air Florida-Western & $\begin{array}{l}\text { Approved by CAB } \\
\text { Not consummated }\end{array}$ \\
\hline 1981 & $\begin{array}{l}\text { Continental-Western } \\
\text { Texas International-Continental }\end{array}$ & $\begin{array}{l}\text { Approved by CAB } \\
\text { Not consummated } \\
\text { Approved by CAB }\end{array}$ \\
\hline 1980 & Republic-Hughes Air West & Approved by CAB \\
\hline 1979 & $\begin{array}{l}\text { Pan American-National } \\
\text { Texas International-National } \\
\text { Eastern-National } \\
\text { Continental-Western } \\
\text { North Central-Southern }\end{array}$ & $\begin{array}{l}\text { Approved by CAB } \\
\text { Approved by CAB } \\
\text { Not consummated } \\
\text { Anticompetitive finding by CAB } \\
\text { Not consummated } \\
\text { Rejected by CAB } \\
\text { Approved by CAB }\end{array}$ \\
\hline
\end{tabular}

Source: Morrison and Winston (1989). 